\title{
The Antioxidant Response System in Wheat Exposed to Pesticides and its Combined-induced Oxidative Damage
}

\author{
Nilgün Candan Yücel, ${ }^{1, *}$ Elif Hakli Heybet ${ }^{2}$ and Ozay Ozgür Gokmen ${ }^{3}$ \\ ${ }^{1}$ Chemistry Department, Dokuz Eylul University, Faculty of Science, Buca, 35160, Izmir, Turkey \\ ${ }^{2}$ Biology Department, Cukurova University, Faculty of Science and Art, 01150, Sarıçam, Balcal, Adana, Turkey \\ ${ }^{3}$ Maize Research Institute, Arifiye, Sakarya \\ *Corresponding author: E-mail: nilgun.candan@deu.edu.tr \\ Tel: +902323019540
}

Received: 26-05-2017

\begin{abstract}
The aim of the present study was to analyze the alterations in the, antioxidant enzyme activities (such as superoxide dismutase (SOD), catalase (CAT), glutathione peroxidase (GSH-Px) and level of glutathione (GSH) and lipid peroxidation (LPO) of wheat acutely treated with CP and DM treatments at low, high doses and their combination. CP and DM were administered to wheat in different doses of 1,1.5, 5 and $35 \mathrm{mg} \mathrm{kg}^{-1}$ given alone and combination. After 3 weeks, antioxidant enzyme activities, and the level of GSH and LPO were recorded and analyzed. Antioxidative defense mechanisms and LPO in wheat display different responses depending on different pesticide treatments and doses. Biochemical analysis showed that exposure of the $\mathrm{CP}$ and DM cause plant tissue damage. It is suggested that appropriate ecotoxicological risk assessment should be made in the areas where DM is proposed to be used in pest control when compared to CP. In the present study, we also concluded that the effect of the combined of CP and DM on the oxidative stress may be synergistic.
\end{abstract}

Keywords: Antioxidant enzymes; lipid peroxidation; pesticide mixture; wheat

\section{Introduction}

With the rapid development of global agriculture, the pesticide risk is receiving increasing consideration. Throughout world, there is a considerable plant exposure to pesticides due to several factors: bioaccumulation and excessive use of pesticides in the agriculture wastes. ${ }^{1}$

From the pesticides, chlorpyrifos (CP, an organophosphate) belongs to the phosphorothioate class of organophosphorus insecticides. ${ }^{2} \mathrm{CP}$, used worldwide (for use in nearly 100 countries and is applied to approximately 8.5 million crop acres each year) unfortunately is a known developmental neurotoxicant. There is increasing evidence that oganophosphorus compounds also induce oxidative stress through generation of free oxygen radicals and cause an imbalance between formation and removal of free radicals, leading to LPO and DNA damage. ${ }^{3}$

Oxidative damage has been recognized as one of the primary causes of subcellular toxicity of pesticides. ${ }^{4}$ Studies on $\mathrm{CP}$ and DM exposure have also suggested a putative role for free radicals in LPO and other oxidative stress-mediated injuries. ${ }^{5,6}$ Also, synthetic pyrethroids (DM, a pyrethroid pesticide) have emerged as a new class of agricultural pesticides and have found wide use over organochlorine and organophosphate pesticides. The use of pyrethroids as insecticidal and anti-parasitic formulations has markedly increased in last 2 decades. ${ }^{7}$ The main advantages of their use are their photostability, high efficacy. ${ }^{8}$ Pyrethroid class of pesticide, such as DM, is globally used in crop protection and control of malaria and other vectorborne diseases.

Insecticides may cause oxidative stress in plant cells, affecting the various metabolic activities and growth components in plants. ${ }^{8}$ It has been well documented that oxidative stress can occur in the cells of plants suffering from severe external environment stress like pesticides. For protection, plants have multiple complex enzymatic and non-enzymatic antioxidant systems including SOD, CAT, and POD.

However, no information is available on the combined effect of CP and DM on the response defense systems 
in plants. The present study was designed to explore the effects of CP, DM and their combination on wheat plant and their relation to free-radical mediated membrane LPO and the influence of the antioxidant defense systems.

\section{Experimental}

\section{1. Plants}

Wheat sterilized seed cultivar (Triticum durum Desf. cv. Yelken) were kept in $1 \%$ sodium hipochloride about 15 $\mathrm{min}$ for sterilizing. Wheat plants were germinated in perlite moistened with saturated $\mathrm{CaSO}_{4}$ solution. Germinated seedlings were bundled in five, fixed with a sponge stripe and transferred to plastic pots containing $2.7 \mathrm{~L}$ of the following continuously aerated nutrient solution: $0.7 \mathrm{mM}$ $\mathrm{K}_{2} \mathrm{SO}_{4}, 2.0 \mathrm{mM} \mathrm{Ca}\left(\mathrm{NO}_{3}\right)_{2}, 0.2 \mathrm{mM} \mathrm{KH} \mathrm{PO}_{4}, 0.75 \mathrm{mM}$ $\mathrm{MgSO}_{4}, 0.1 \mathrm{mM} \mathrm{KCl}, 100 \mu \mathrm{M}$ FeEDTA, $1 \mu \mathrm{M} \mathrm{H}_{3} \mathrm{BO}_{3}, 0.5$ $\mu \mathrm{M} \mathrm{MnSO}_{4}, 0.2 \mu \mathrm{M} \mathrm{CuSO}_{4}$, and $0.02 \mu \mathrm{M}\left(\mathrm{NH}_{4}\right)_{6} \mathrm{Mo}_{7} \mathrm{O}_{24}$. Each treatment was replicated three times. Plants were grown in a climate chamber set to light-dark cycles of 16-8 $\mathrm{h}$ with a photosynthetic photon flux density of $450 \mu \mathrm{mol}$ $\mathrm{m}^{-2} \mathrm{~s}^{-1}$ at plant height during the light cycle and a temperature regime of $24-20^{\circ} \mathrm{C}$ during the light-dark cycles. Nutrient solutions were renewed every three days.

Seven-day-old seedlings were subjected to foilar application of five concentrations of CP, DM and their combination.

After 3 weeks of treatment, plant MDA level and SOD, GSH-Px, and CAT activities were determined.

Tissue extracts of wheat plants were prepared for enzyme activity determinations. One g material was homogenized in $4 \mathrm{ml} 20 \mathrm{mM}$ phosphate buffer (pH 7.4). The homogenate was then centrifuged at $15000 \times g$ for $15 \mathrm{~min}$. The supernatant was used for enzyme analysis. All operations (until the enzyme determination) were done at $4{ }^{\circ} \mathrm{C}$.

\section{2. Enzymatic Assays}

The SOD assay was based on the inhibitory effects of SOD on the spontaneous autoxidation of 6-hydroxydopamine. ${ }^{9}$ One IU is the amount of SOD required to inhibit the initial rate of 6-hydroxydopamine autoxidation by $50 \%$. CAT activity was assayed in a reaction mixture containing $25 \mathrm{mM}$ phosphate buffer ( $\mathrm{pH} 7.0) 10.5 \mathrm{mM} \mathrm{H}_{2} \mathrm{O}_{2}$, and enzyme. The decomposition of $\mathrm{H}_{2} \mathrm{O}_{2}$ was followed at $240 \mathrm{~nm}\left(\mathrm{E}=39.4 \mathrm{mM}^{-1} \mathrm{~cm}^{-1}\right) \cdot{ }^{10}$ One IU of enzyme activity is the amount of the enzyme, which decomposes $1 \mu \mathrm{mol}$ $\mathrm{H}_{2} \mathrm{O}_{2}$ per min at $25^{\circ} \mathrm{C}$. The determination of GSH-Px activity was based on the method of Paglia and Valentine. ${ }^{11}$ GSH-Px catalyses the oxidation of GSH by cumene hydroperoxide. In the presence of GSH reductase and NA$\mathrm{DPH}$, the oxidized glutathione is immediately converted to the reduced form with a concomitant oxidation of NA$\mathrm{DPH}$ to $\mathrm{NADP}^{+}$. The decrease in absorbance of NADPH was measured at $340 \mathrm{~nm}$.

\section{3. Non-enzymatic Assays}

GSH was estimated based on Ellman 5,5'-Dithiobis(2-nitrobenzoic acid) (DTNB) reactivity. Samples were evaluated for colored component production using a spectrophotometric assay for DTNB at $412 \mathrm{~nm} .^{12}$

LPO was estimated based on thiobarbituric acid (TBA) reactivity. Samples were evaluated for MDA production using a spectrophotometric assay for TBA. ${ }^{13}$ The extinction coefficient of $153 \mathrm{mM}^{-1} \mathrm{~cm}^{-1}$ at $532 \mathrm{~nm}$ for the chromophore was used to calculate the MDA-like TBA.

The total protein content was determined by the method of Bradford using bovine serum albumin (BSA) as standard (data not shown). ${ }^{14}$

Data are given as mean \pm standard deviation. Statistical analysis of data was performed on computer by using SPSS Version 11.0. Kruskal Wallis was used for comparision of six groups. If a difference was detected by using Kruskal Wallis test, the Bonferonni-corrected Mann-Whitney $\mathrm{U}$ test was used to determine which two groups were significantly different.

\section{4. Fresh Weight and Shoots Length}

The fresh weight of whole seedlings (roots included) and shoot length was measured at $7^{\text {th }}, 14^{\text {th }}$ and $21^{\text {th }}$ days.

\section{Results and Discussion}

Antioxidative defense mechanism and LPO in wheat tissues display different responses depending on different pesticide treatments ( $\mathrm{CP}$ as an organophosphate, $\mathrm{DM}$ as a pyrethroid pesticide) and doses. All the results from various treatment groups have been compared to each other and to control.

Biochemical analysis showed that there was a significant increase in MDA level of plant after low- and high-doses pesticide (CP, DM) treatments compared to control (Fig. 1). At high doses of DM and CP, the wheat showed remarkable increase LPO levels compared to those of low dose of DM and CP treatments $(\mathrm{p}<0,001)$. The highest LPO levels in plant were observed as $295.17 \%$ in high dose CP treatment and as $226.03 \%$ in high dose DM treatment when compared with control plant. DM and CP combination group of plants showed significant maximum LPO level (308.97\%) respect to control.

The results of the present study clearly demonstrate that CP, DM and their combination produced adverse effects on wheat plants, the major symptoms were reduced growth, disruption of the antioxidant system and significantly increased of LPO level.

However, the relative responses of LPO affected by $\mathrm{CP}$ were more pronounced than in case of DM. According to the present experiments, we concluded that LPO may be one of the molecular mechanisms involved in CP and DM-induced toxicity. Also the same mechanism may be operated for DM treatment caused the LPO induction. 


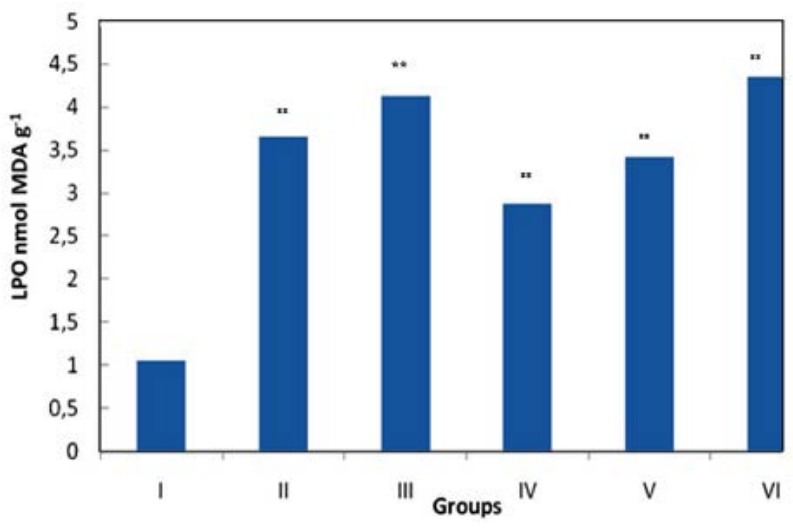

Figure 1. Effect of chlorpyrifos and deltamethrin on the wheat plant lipid peroxidation as measured by MDA value. CP and DM were administered in different doses. Group I (control group), group II (1 $\mathrm{mg} \mathrm{kg}{ }^{-1} \mathrm{CP}$ group), group III (15 $\mathrm{mg} \mathrm{kg}^{-1} \mathrm{CP}$ group), group IV (5 $\mathrm{mg} \mathrm{kg}{ }^{-1} \mathrm{DM}$ group), group $\mathrm{V}$ (35 $\mathrm{mg} \mathrm{kg}^{-1} \mathrm{DM}$ group), group VI (combination group of $1 \mathrm{mg} \mathrm{kg}^{-1} \mathrm{CP}$ and $5 \mathrm{mg} \mathrm{kg}^{-1} \mathrm{DM}$ ). Values are represented as means ${ }^{* *}$ significantly different from control at $\mathrm{P}<$ 0.001 .

The observed activities of antioxidative enzymes such as SOD (a scavenger of superoxides), CAT (a scavenger of $\mathrm{H}_{2} \mathrm{O}_{2}$ ) and GSH-Px are shown in Table. 1.

Table 1. Effect of CP and DM on the SOD, CAT and GSH-Px activities of wheat plant. Values are represented as means S.D. of eight plants in each group. ${ }^{* *}$ Significantly different from control at $\mathrm{P}<$ 0.001 .

\begin{tabular}{|c|c|c|c|}
\hline \multicolumn{4}{|c|}{ Antioxidant Enzyme Activities } \\
\hline Groups & $\begin{array}{c}\text { SOD } \\
(\mathrm{IU} / \mathbf{m g})\end{array}$ & $\begin{array}{c}\text { CAT } \\
\text { (IU/mg) }\end{array}$ & $\begin{array}{c}\text { GSH-Px } 10^{3} \\
\text { (IU/mg) }\end{array}$ \\
\hline I & 61.43 & 132.23 & 51.31 \\
\hline II & $96.87^{* *}$ & $211.36^{\star *}$ & 59.30 \\
\hline III & 82.18 & 150.62 & $29.03^{* *}$ \\
\hline IV & 76.14 & 147.79 & $78.68^{\star *}$ \\
\hline $\mathrm{V}$ & $116.51^{\star \star}$ & $306.41^{\star *}$ & 71.27 \\
\hline VI & $118.09^{* *}$ & 160.00 & 64.53 \\
\hline
\end{tabular}

SOD activities were significantly increased in both pesticide treatment groups (Table 1). While SOD activities in the $\mathrm{CP}$ treatment group showed a negative correlation with $\mathrm{CP}$ concentration, DM treatment group displayed a positive correlation with the concentration. The maximum SOD activity was observed in DM and CP combination group of plants as $88.74 \%(\mathrm{p}<0.001)$.

GSH-Px activities were significantly increased in wheat tissues except for high dose $\mathrm{CP}$ treatment group (Table 1). GSH-Px activities in plants showed a negative correlation with $\mathrm{CP}$ and DM concentrations. The maximum GSH-Px activity was observed in low dose DM group of plants as $53.34 \%(\mathrm{p}<0.001)$.

CAT activities were significantly increased in all groups (Table 1). While CAT activities in wheat showed a negative correlation with $\mathrm{CP}$ concentration, a positive correlation was observed due to the DM concentration. The maximum increase was observed in high dose DM group as $131.62 \%(\mathrm{p}<0.001)$.

GSH levels in wheat plants were decreased in all groups except for low dose $\mathrm{CP}$ treatment group showed a negative correlation with $\mathrm{CP}$ and DM concentrations (Fig. 2).

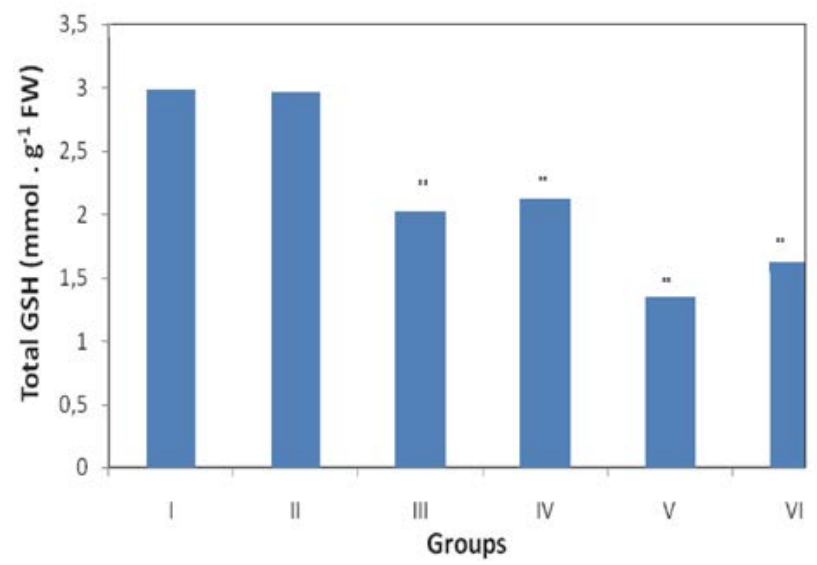

Figure 2. Effect of chlorpyrifos and deltamethrin on the wheat GSH level. CP and DM were administered in different doses. Group I (control group), group II (1 $\mathrm{mg} \mathrm{kg}^{-1} \mathrm{CP}$ group), group III (15 mg kg-1 CP group), group IV (5 mg kg-1 DM group), group V (35 $\mathrm{mg} \mathrm{kg}^{-1} \mathrm{DM}$ group), group VI (combination group of $1 \mathrm{mg} \mathrm{kg}^{-1} \mathrm{CP}$ and $5 \mathrm{mg} \mathrm{kg}^{-1}$ DM). Values are represented as means \pm S.D. of eight plants in each group. " Significantly different from control at $\mathrm{P}<0.001$.

Fresh weight and shoot length in wheat plants were decreased in all groups and the maximum decreases were observed in DM and CP combination group of plants as $86.64 \%$ and $83.64 \%$, respectively $(\mathrm{p}<0.001)$ (Table 2.$)$.

It appears that the cells under stress increase the production of antioxidant enzymes that scavenge the free radicals. ${ }^{15}$ Once free radicals are formed, the cells start some physiological defense mechanisms to prevent the damage. SOD, CAT and GSH-Px activities at $1 \mathrm{mg} \mathrm{kg}^{-1}$ increased activities, while $15 \mathrm{mg} \mathrm{kg}^{-1}$ decreased those. It is highly likely that 3 weeks of treatment with $15 \mathrm{mg} \mathrm{kg}^{-1}$ of $\mathrm{CP}$ caused more wheat tissue injury than did $1 \mathrm{mg} \mathrm{kg}^{-1}$. The negative correlation could be a reflection of tissue loss due to the toxic action of these pesticides. Some studies indicated that superoxide radicals can inhibit GSH-Px ${ }^{16}$ and CAT activities ${ }^{17}$, and singlet oxygen and peroxyl radicals can inhibit SOD and CAT activities. ${ }^{18}$ As pointed out by Oncu et al., if CP inhibits GSH-Px and CAT significantly via $\mathrm{ROS}$ induced by $\mathrm{CP}, \mathrm{H}_{2} \mathrm{O}_{2}$ will accumulate. ${ }^{19}$ The increased $\mathrm{H}_{2} \mathrm{O}_{2}$ could cause SOD inhibition, so that superoxide radicals would increase. The increased superoxide radicals would inhibit both CAT and GSH-Px so that $\mathrm{H}_{2} \mathrm{O}_{2}$ would accumulate in the medium, causing SOD inhibition and increased superoxide radicals. The observed inhibitions of SOD, CAT and GSH-Px may be due to the direct effect of $\mathrm{CP}$ or due to the effect of ROS induced by $\mathrm{CP}$ or both. 
Table 2. Growth parameters: Fresh weight and \% Germination of wheat for different treatments

\begin{tabular}{llccc}
\hline $\begin{array}{l}\text { Growth } \\
\text { parameters }\end{array}$ & $\begin{array}{l}\text { Treatments } \\
(\%+\mathbf{m M})\end{array}$ & $\mathbf{7}$ & $\mathbf{1 4}$ & $\mathbf{2 1}$ \\
\hline Fresh weight $(\mathrm{mg})$ & I & $60 \pm 2$ & $150 \pm 2$ & $189 \pm 3$ \\
& II & $52 \pm 2$ & $110 \pm 2^{\delta}$ & $183 \pm 8^{\varepsilon}$ \\
& III & $45 \pm 2$ & $102 \pm 2^{\delta}$ & $173 \pm 9^{\varepsilon}$ \\
& IV & $50 \pm 2$ & $130 \pm 2^{\delta}$ & $162 \pm 5^{\varepsilon}$ \\
& V & $40 \pm 2$ & $120 \pm 09^{\varepsilon}$ & $140 \pm 4^{\varepsilon}$ \\
& VI & $30 \pm 2$ & $95 \pm 11^{\delta}$ & $119 \pm 11^{\varepsilon}$ \\
\hline Shoot length (cm) & I & $5.2 \pm 2$ & $11.3 \pm 2$ & $20.2 \pm 2$ \\
& II & $4.9 \pm 2$ & $10.5 \pm 2$ & $19.2 \pm 2$ \\
& III & $4.6 \pm 2$ & $9.9 \pm 2$ & $18.1 \pm 2$ \\
& IV & $3.9 \pm 2$ & $9.5 \pm 2$ & $16.5 \pm 2$ \\
& V & $3.5 \pm 2$ & $9.4 \pm 2$ & 16.4 \\
& VI & $2.9 \pm 2$ & $8.7 \pm 2$ & 14.4 \\
\hline
\end{tabular}

Data are 'mean \pm S.D' the mean \pm SD of three independent experiments.

${ }^{\delta} \mathrm{p}<0.05$ (probably significant) ${ }^{\varepsilon} \mathrm{p}<0.01$ (definitely significant)

In the present study, significant elevations in the SOD and CAT activities were indicated in DM-toxicated plants with increasing dose. These results show that SOD and CAT display co-operative functions for preventing a partial protection of membrane lipid against oxidative stress under DM treatment compared to CP treatment.

GSH is an important antioxidant system of most aerobic cells. ${ }^{20}$ It plays a key role as a cofactor with a variety of enzymes including GSH-Px. GSH depletion has been shown to intensify LPO and predispose cells to oxidant damage. ${ }^{21}$ This study demonstrates that enhanced CP and DM concentrations effect on GSH loss and LPO elevation in wheat plants. When the relative responses of LPO and GSH were compared, effects of these pesticides were more pronounced in case of decrease in GSH than the LPO induction in wheat plants. Thus, it is concluded that endogenous GSH plays an important protective role against $\mathrm{CP}$ than DM and induced oxidative damage in vivo.

Groten et al., suggest that a simple mixture should be evaluated by testing each individual compound separately, and thereafter different combinations of the compounds. ${ }^{22}$ Testing mixture in this way, it would be possible to identify the compound(s) responsible for possible interactions. As mixture models improve, more precise data throughout the toxicity range could be required. More research on pesticide mode of toxic action and secondary physiological effects caused by pesticides would provide a platform for understanding the physiology of mixture effects, lead to better predictive models, and allow for rational experimental design. We believe that these types of studies are critical for realistic estimations of toxicity, because rarely are organisms exposed to only a single chemical in the field. In the present study, the two pesticides (CP and DM) were tested individually, and one combination group. It was shown that inhibition of GSH level in the combination group induced LPO level. These observations suggest that the effect of combination of $\mathrm{CP}$ and $\mathrm{DM}$ on the oxidative stress may be synergistic.

Pesticides before authorized and registered to be used in European Union (EU), member states undergo extensive chemical, biological (effectiveness), toxicological and environmental behaviour scrutiny investigations in the field of water policy. ${ }^{23}$ According to this prioritization approach 71 pesticides were identified as being pollutants in the Pinios River Basin of Central Greece reflecting the current situation of land use and agricultural practices. ${ }^{24}$ $\mathrm{CP}$ ranked first potential hazardous candidate for the Pinios River basin and DM did not rank as a potential hazardous. In the present study, we also concluded that the effect of the combined of CP and DM biochemical behavior scrutiny may be much better than DM alone.

\section{Conclusions}

These data present evidence that, CP and DM treatments lead to enhanced toxicity in wheat plant in relation to dose. The enhancements of LPO suggest the involvement of free radicals intermediates in these pesticide toxicities. The existence of an inducible antioxidant system may reflect an adaptation by the organism. Increased antioxidant defense system of wheat resulted in partial protection of membrane lipid against oxidative stress under DM treatment compared to $\mathrm{CP}$.

\section{References}

1. C. G. Castillo, M. Montante, L. Dufour, M. Martinez, M. E. Jimenez-Capdeville, Neurotoxic. Teratol 2002, 24, 797-804.

DOI:10.1016/S0892-0362(02)00268-4

2. R. J. Richardson, T. B. Moore, U. S. Kayyali, J. H. Fowke, J. C. 
Randall, Fundam. Appl. Toxicol. 1993, 20, 273-279.

DOI:10.1006/faat.1993.1036

3. D. Bagchi, M. Bagchi, E. A. Hassoun, S. J. Stohs, Toxicol 1995, 104, 129-40. DOI:10.1016/0300-483X(95)03156-A

4. L. Liang, Y. L. Lu, H. Yang, 2012, Environ. Sci. Pollut. R. 19, 2044-2054. DOI:10.1007/s11356-011-0698-7

5. M. I. Yousef, T. I. Awad, E. H. Mohamed, Toxicol. 2006, 227, 240-247. DOI:10.1016/j.tox.2006.08.008

6. S. P. Bradburry, J. R. Coast, Rev. Environ. Contam. Toxicol. 1989, 108, 134-77. DOI:10.1007/978-1-4613-8850-0_4

7. Y. Shukla, A. Arora, A. Singh, Toxicol. 2001, 163, 1-9. DOI:10.1016/S0300-483X(00)00416-9

8. F. Bashir, T. O. Siddiqi, Mahmooduzzafar, M. Iqbal, Environ. Pollut. 2007, 147, 94-100. DOI:10.1016/j.envpol.2006.08.013

9. N. Crosti, T. Servedi, J. Bajer, A. Sera, J. Clin. Chem. Clin. Biochem. 1987, 25, 265-267.

10. H. E. Aebi, 1983, Catalase, In: Methods of Enzymatic Analysis, $3^{\text {rd }}$ Ed., Deerfield Beach, Florida: Verlag Chemic, pp. 273286.

11. D. E. Paglia, W. N. Valentine, J. Lab. Clin. Med. 1967, 70, 158169.

12. F. Tietze, Anal. Biochem. 1969, 27, 502-522. DOI:10.1016/0003-2697(69)90064-5

13. H. H. Draper, M. Hadley, Methods. Enzymol. 1990, 186, 421431. DOI:10.1016/0076-6879(90)86135-I
14. M. M. Bradford, Anals. Biochem. 1976, 72, 248-252. DOI:10.1016/0003-2697(76)90527-3

15. B. D. Banerjee, V. Seth, R. S. Ahmed, Rev. Environ. Health. 2001, 16, 1-40. DOI:10.1515/REVEH.2001.16.1.1

16. D. Debnath, T. K. Mandal, J. Applied. Toxicol. 2000, 20, 197204. DOI:10.1002/(SICI)1099-1263(200005/06)20:3<197:: AID-JAT634>3.0.CO;2-7

17. J. L. Freeman, M. W. Persans, K. Nieman, Plant Cell 2004, 16, 2176-2191. DOI:10.1105/tpc.104.023036

18. F. Gultekin, M. Ozturk, M. Akdogan, Arch. Toxicol. 2000, 74, 533-538, 2000. DOI: $10.1007 / \mathrm{s} 002040000167$

19. J. A. Escobar, M. A. Rubio, E. A. Lissi, Free Radic Biol Med. 1996, 20, 285-290. DOI:10.1016/0891-5849(95)02037-3

20. D. Dolphin, R. Poulson, R. Avramovic, 1998, Glutathione: chemical, biochemical and medical aspects, Willey, New York, NY Parts A and B.

21. R. G. Nath, J. E. Ocanda, J. P. Richie, F. L. Chung, Chem Res Toxicol. 1997, 10, 1250-1253. DOI:10.1021/tx9701079

22. J. P. Groten, V. J. Feron, J. Sühnel, Trends. Pharmacol. 2001, 31,316-321. DOI:10.1016/S0165-6147(00)01720-X

23. European Commission (EU) 2013. Decision 2013/39/EC on environmental quality standards in the field of water policy. Off. J. Eur. Communities (2013), L 226/1 (12.08.2013).

24. A. Tsaboula, E. N. Papadakis, Z. Vryzas, A. Kotopoulou, K. Kintzikoglou, Environ. Inter. 2016, 91, 78-93.

DOI:10.1016/j.envint.2016.02.008

\section{Povzetek}

Cilj te študije je bil analizirati spremembe v aktivnostih antioksidantnih encimov (kot so superoksid dismutaze (SOD), katalaze (CAT), glutation peroksidaze (GSH-Px) in stopnje peroksidacije glutationa in lipidov (LPO) pšenice akutno zdravljenie s klorpirifosom in deltametrinskim zdravljenjem pri nizkih in visokih odmerkih in njihovi kombinaciji. Klorpirifos (CP) in deltametrin (DM) so dajali pšenici v različnih odmerkih po 1, 1,5, 5 in $35 \mathrm{mg} \mathrm{kg}^{-1}$, samostojno in v kombinaciji. Po 3 tednih so bile zabeležene in analizirane stopnje antioksidantnih encimov ter ravni glutationa GSH, askorbata in lipidov. Antioxidativni obrambni mehanizmi in peroksidacija lipidov pri pšenici kažejo različne odzive, odvisno od različnih pesticidov in odmerkov. Biokemijske analize so pokazale, da klorpirifos in deltametrin povzročata poškodbe rastlinskega tkiva. Predlagamo, da se ustrezno oceni ekotoksikološko tveganje na območjih, kjer se deltametrin uporablja za zatiranje škodljivcev v primerjavi s klorpirifosom. V tej študiji smo ugotovili tudi, da je lahko učinek kombinacije klorpirifosa in deltametrina sinergističen. 